\title{
Effectiveness of Methanol Solvent Extraction for Red Macroalgae Acanthophora spicifera Antitumoric Activity
}

\author{
Eka Sunarwidhi Prasedya' ${ }^{1}$ Ni Wayan Riyani Martyasari², Candra Dwipayana Hamdin², Masao Miyake ${ }^{4}$, \\ Daisuke Kobayashi ${ }^{4}$, Sri Widyastuti ${ }^{3}$, Akihiro Hazama ${ }^{4}$, Haji Sunarpi ${ }^{1, *}$
}

\section{Eka Sunarwidhi Prasedya', Ni Wayan Riyani Martyasa- $\mathrm{ri}^{2}$, Candra Dwipayana Hamdin², Masao Miyake ${ }^{4}$, Daisuke Kobayashi ${ }^{4}$, Sri Widyastuti ${ }^{3}$, Akihiro Hazama ${ }^{4}$, Haji Sunarpi ${ }^{1, *}$}

'Bioscience and Biotechnology Research Centre, Faculty of Mathematics and Natural Sciences, University of Mataram, Nusa Tenggara Bar-83126, INDONESIA.

${ }^{2}$ Department of Pharmacy, Medical Faculty, University of Mataram, Nusa Tenggara Bar-83126, INDONESIA. ${ }^{3}$ Faculty of Food Science and Agroindustrial Technology, University of Mataram, Nusa Tenggara Bar-83126 INDONESIA.

${ }^{4}$ Department of Cellular and Integrative Physiology, Fukushima Medical University, Fukushima, JAPAN.

Correspondence

Prof. Haji Sunarpi.

Department of Biology, Faculty of Mathematics and Natural Sciences, Bioscience and Biotechnology Research Centre, University of Mataram, Mataram-83115, INDONESIA.

Phone no : +6285954592857

E-mail: ekasprasedya@unram.ac.id

History

- Submission Date: 18-07-2018;

- Review completed: 25-08-2018.

- Accepted Date: 12-02-2019

DOI : 10.5530/pj.2019.11.70

Article Available online

http://www.phcogj.com/v11/i3

Copyright

(C) 2019 Pharmacognosy Journal. This is an open-access article distributed under the terms of the Creative Commons Attribution 4.0 International license.

\begin{abstract}
Introduction: Red macroalgae Acanthophora spicifera is commonly found in most parts of Indonesia coastal areas. However, information regarding their potential pharmaceutical uses remains largely unexplored. This study evaluates the antiproliferative activity of Acanthophora spicifera collected from Indonesian extracted with different solvents of ethanol and methanol. Methods: Cytotoxicity and antiproliferative activity of $A$. spicifera crude ethanol extract $(\mathrm{AS}-\mathrm{EtOH})$ and $A$. spicifera crude methanol extract (AM-MetOH) were evaluated with Lactate dehidrogenase (LDH) and Trypan blue exclusion assay in Human cervical cancer (HeLa) cells for $72 \mathrm{~h}$. Concentration of extracts treated in HeLa cells were 6.25 to $200 \mu \mathrm{g} / \mathrm{mL}$. Viability staining with fluorescence stain Hoechst33342/PI was conducted to investigate apoptotic activity. Potential apoptotic activity of treatments was confirmed by DNA fragmentation assay. Results: AS-MetOH demonstrated high cytotoxicity in HeLa cells with $I_{50}$ of $127.3 \pm 33.13 \mu \mathrm{g} / \mathrm{mL}$. However, AS-EtOH IC ${ }_{50}$ values could not be determined in this study. Antiproliferative activity was highly significant in AS-MetOH treated cells as cell density was suppressed to $20 \times 10^{4}$ cells $/ \mathrm{mL}$ compared to AS-EtOH $\left(73 \times 10^{4}\right.$ cells $\left./ \mathrm{mL}\right)$ and untreated cells $\left(83 \times 10^{4} \mathrm{cells} / \mathrm{mL}\right)$ Finally, apoptotic activity could be determined in AS-MetOH treated cells with increase PI fluorescence emitting cells and DNA fragmentation. On the other hand, apoptotic activity was not observable in AS-EtOH treated cells based on fluorescence viability staining and DNA fragmentation assay. Conclusion: Current results show methanol solvent as an effective solvent to promote potential pharmaceutical properties of macroalgae $A$. spicifera. Further advanced studies in a compound level from $A$. spicifera methanol fraction would be reasonable for development of macroalgae based anticancer agent.
\end{abstract}

Key words: Acanthophora, Antiproliferative, Cytotoxicity, Indonesia, Macroalgae.

\section{INTRODUCTION}

Cancer is a leading cause of death worldwide after cardiovascular diseases. Although various anticancer agents have been discovered and are in use currently, cancer treatment remains a large health challenge. ${ }^{1}$ Common cancer treatments such as chemotherapy are well known to result an adverse side effects. ${ }^{2}$ The costs of such treatments are unaffordable for most people particularly in developing countries such as Indonesia. Hence, research on discovery of alternative and complementary anticancer drugs from natural products continues to increase in rapid pace. Indonesia is a country with high diversity, especially in parts of its oceans which most of the bioresources remain largely unexplored. Recent studies have evidenced medicinal potentials of marine organisms as potential source of anticancer agents. ${ }^{3}$ Macroalgae or seaweeds are one example of marine organisms which provide promising anticancer activity. ${ }^{4,5}$ An extract from the brown seaweed Sargassum thunbergii has shown antitumour activity and inhibition of tumour metastasis in the rat mammary adeno carcinoma cell. ${ }^{6}$ Some studies recently also evaluated the effect of a brown seaweed (Sargassum muticum) methanol extract on the proliferation of MCF-7 and MDA-MB-231 breast cancer cells by conducting morphological assessments of apoptosis, caspase assays and chick Chorioallantoic Membrance (CAM) assays. ${ }^{7}$ Indonesia is well known for its optimal condition for macroalgae growth. Despite its abundance, there remains little information regarding potential utilizations of macroalgae in pharmaceutical industries.

One common red macroalgae species which is commonly found in Indonesian coastal areas is Acanthophora spicifera. The alcoholic extract of the red algae Acanthophora spicifera exhibit antitumor activity on Ehrlich's ascites carcinoma cells developed in mice at a dose of $20 \mathrm{mg} / \mathrm{kg}$, comparable to the standard drug 5 -flurouracil. ${ }^{9}$ This is evidenced by increase in the mean survival time, decrease in tumor volume and viable cell count. Furthermore, the seaweeds Acanthophora spicifera, Ulva reticulate, Gracilaria foliifera and Padina boergesenii of the
Cite this article: Prasedya ES, Martyasari NWR, Hamdin CD, Miyake M, Kobayashi D, Widyastuti S, Hazama A, Sunarpi H. Effectiveness of Methanol Solvent Extraction for Red Macroalgae Acanthophora spicifera Antitumoric Activity. Pharmacog J. 2019;11(3):450-4. 
Gulf of Manna region are evidenced to demonstrate cytotoxic activity in their alcoholic extracts. ${ }^{3}$ However, the cytotoxic effect of $A$. spicifera reported in previous study is considered as low cytotoxic activity $\left(\mathrm{IC}_{50} \geq 500 \mu \mathrm{g} / \mathrm{mL}\right)$. Hence, in our study we evaluate the effectiveness of methanol solvent in cytotoxic activitiy of Acanthophora against human cancer cells. Our current result would provide information regarding potential development of Acanthophora spicifera from Indonesian coastal areas in medicinal and pharmaceutical industries.

\section{MATERIALS AND METHODS}

\section{Sample collection and extraction}

Red macroalgae Acanthophora spicifera were collected from North West Lombok coastal area $\left(8^{\circ} 24^{\prime} 11.7396^{\prime \prime} \mathrm{S}, 116^{\circ} 4^{\prime} 1.9056^{\prime \prime} \mathrm{E}\right)$, West Nusa Tenggara Province, Indonesia in the end of 2017. Macroalgae specimens were identified according to electronic algae database. ${ }^{10}$ The seaweed samples were washed with freshwater to remove adhering debris. The collected samples were then dried and powdered. Powder samples were mixed with absolute ethanol solvent with $5 \mathrm{x}$ volume of sample weight $(\mathrm{w} / \mathrm{v})$. Suspensions were then macerated by incubation in room temperature for $48 \mathrm{~h}$. Every $24 \mathrm{~h}$, suspensions were filtered with Whatman number 1 filter papers. Filtrates were evaporated with rotary evaporators until concentrated ethanol extracts were obtained. These filtrates were then used for seaweed ethanol extracts. Same procedure was conducted to obtain methanol extracts. ${ }^{11}$

\section{Chemicals and reagents}

2-(4-Iodophenyl)-3-(4-nitrophenyl)-5-(2,4-disulfophenyl)-2H-tetrazolium, monosodium salt (WST-1), 1-methoxyl-5-methylphenazinium methylsulfate (1-Met-PMS) were purchased from Dojindo Laboratories, (Kumamoto, Japan), nicotinamide adenine dinucleotide (NAD) was obtained from Oriental Yeast. Co. Ltd. (Tokyo, Japan). General reagents including lithium lactate were purchased from Wako Pure Chemicals (Osaka, Japan).

\section{Preparation of macroalgae extract for analysis}

Powdered seaweed (50 g) was extracted successively using Soxhlet extractor sequentially with different solvents of increasing polarity of ethanol until the extract was clear. The resulting pasty extracts were stored in a refrigerator at $4^{\circ} \mathrm{C}$ for further use. The extraction was centrifuged at $15,000 \times g$ for $10 \mathrm{~min}$. The supernatant was collected and dried and stored at $4^{\circ} \mathrm{C}$ until future use. The dried macroalgae extract was resolved in Dimethyl Sulfoxide (DMSO) and centrifuged at 15,000 $\times g$ for $15 \mathrm{~min}$, then obtained clear macroalgae extract sample.

\section{Cell culture}

Human cervical cancer cell line (HeLa) cells were routinely cultivated in Dulbecco's Modified Eagle Medium (DMEM, Wako) supplemented with $10 \%$ fetal bovine serum at $37^{\circ} \mathrm{C}$ in a $5 \% \mathrm{CO}_{2}$ humidified incubator. For all experiments, HeLa cells were plated in DMEM, incubated overnight and incubated in DMEM supplemented with specific concentrations of macroalgae extracts. Cell images were obtained from phase-contrast microscopy by BZ-9000 microscope (Keyence, Osaka, Japan).

\section{Cytotoxicity Assay and cell proliferation}

Cytotoxicity of AS-EtOH and AS-MetOH were estimated by Lactate Dehydrogenase (LDH) assay and cell proliferation was measured by Trypan blue dye exclusion assay. ${ }^{12}$ Cells were cultured in 96-well culture plate over-night, then the culture mediums were discarded and changed with new medium containing several concentrations $(6.25-200 \mu \mathrm{g} / \mathrm{mL})$ of AS-MetOH and AS-EtOH. After $24 \mathrm{~h}$ incubation, a portion of the culture medium $( \pm 100 \mu \mathrm{L})$ was transferred to another 96-well plate, which contained $2.5 \mathrm{mM}$ NAD, $50 \mathrm{mM}$ lithium lactate, $100 \mathrm{mMTris}(\mathrm{pH} 8.0$ ), $0.04 \mathrm{mM}$ 1-Met-PMS and $1 \mathrm{mM}$ WST-1. Colouring change depended on $\mathrm{LDH}$ activity was measured by absorbance at $450 \mathrm{~nm}$. Maximum absorbance $\left(\mathrm{A}_{450 \max }\right)$ was obtained from completely dead cells by addition of $1 \%$ Triton $\mathrm{X}-100$ in the cell culture and minimum absorbance $\left(\mathrm{A}_{450 \min }\right)$ was obtained from the control cell culture. Cytotoxicity was calculated by the following equation; Cytotoxicity $(\%)=\left(\mathrm{A}_{450 \text { treatment }}-\mathrm{A}_{450 \mathrm{~min}}\right) /$ $\left(A_{450 \max }-A_{450 \min }\right) \times 100$. Cell proliferation was measured by counting cell number under microscopic observation. The cell suspension was mixed with equal volume of $0.4 \%$ Trypan blue dye. Viability was indicated as the ratio of live cells to total cells.

\section{Hoechst33342-PI viability staining}

Cells were incubated with macroalgae extracts with maximum concentration of $200 \mu \mathrm{g} / \mathrm{mL}$ for $72 \mathrm{~h}$. For early detection of apoptotic activity, cells were subjected to Hoechst $33342 / \mathrm{PI}$ viability staining. ${ }^{13}$ Treated cells were stained $2 \mu \mathrm{L}$ volume of Hoechst 33342 and incubated for $15 \mathrm{~min}$ in $\mathrm{CO}_{2}$ and $37^{\circ} \mathrm{C}$ incubator. Followed by staining with Propidium Iodide (PI) with the same volume and analyzed using fluorescence microscopy and ImageJ software.

\section{DNA fragmentation}

The cells were incubated with $100 \mu \mathrm{g} / \mathrm{mL}$ concentration of AS-EtOH and AS-EtOH for 3 days. ${ }^{14}$ The treated cells were collected by trypsinization. DNA was extracted once, with an equal volume of phenol: chloroform: isoamyl alcohol (25:24:1) and once with chloroform: isoamyl alcohol (24:1). The DNA was precipitated with a two-thirds volume of cold isopropanol followed by centrifugation. The DNA pellet was washed once in $70 \%$ ethanol and resuspended in deionized water containing $0.1 \mathrm{mg} / \mathrm{mL}$. DNA was analyzed by $1.5 \%$ agarose gel electrophoresis. Staurosporine (STS) was used as positive control.

\section{Statistical analysis}

Student's $t$-test was used to analyze intergroup differences. Experiments were repeated at least three times and data are represented as the mean $\pm \mathrm{SD}$. A $p$-value of less than 0.05 was considered to be statistically significant.

\section{RESULTS}

\section{Cytotoxicity and antiproliferative assay}

Cytotoxicity and antiproliferative effects of red seaweed AS-EtOH and AS-EtOH extracts were investigated via Lactate Dehydrogenase (LDH) assay against HeLa human cervical cancer cell line. Cytotoxic activity of Acantohphora spicifera methanol extracts increased in a dose-dependent manner (Sure 1). After $72 \mathrm{~h}$, the $\mathrm{IC}_{50}$ value of AS-MetOH crude extract was $127.3 \pm 33.13 \mu \mathrm{g} / \mathrm{mL}$. Whereas, $\mathrm{IC}_{50}$ value of AS-EtOH crude extract could not be determined in this study. AS-EtOH and AS-MetOH antiproliferative effects were determined with cell count by trypan blue exclusion assay. Figure 2 shows that untreated cells show high cell density with total cell count approximately $80 \times 10^{4}$ cells $/ \mathrm{mL}$ in $72 \mathrm{~h}$. Treated with AS-MetOH extracts resulted in suppressed cell density $\left(23 \times 10^{4}\right.$ cells $\left./ \mathrm{mL}\right)$. In contrast, cell density in AS-EtOH treated cells $\left(73 \times 10^{4}\right.$ cells $\left./ \mathrm{mL}\right)$ shows no antiproliferative activity.

\section{Hoechst3342-PI viability staining}

Cell morphology observation under fluorescence microscope shows that untreated HeLa cells shown normal elongated cell shapes (Figure 3). Viability staining with double staining Hoechst33342/PI stained live/ dead cells; blue fluorescence dye Hoechst33342 and dead cells were stained red fluorescence dye Propidium Iodide (PI). These nucleic dyes would bind to specific regions in DNA, so stained particles are assumed 


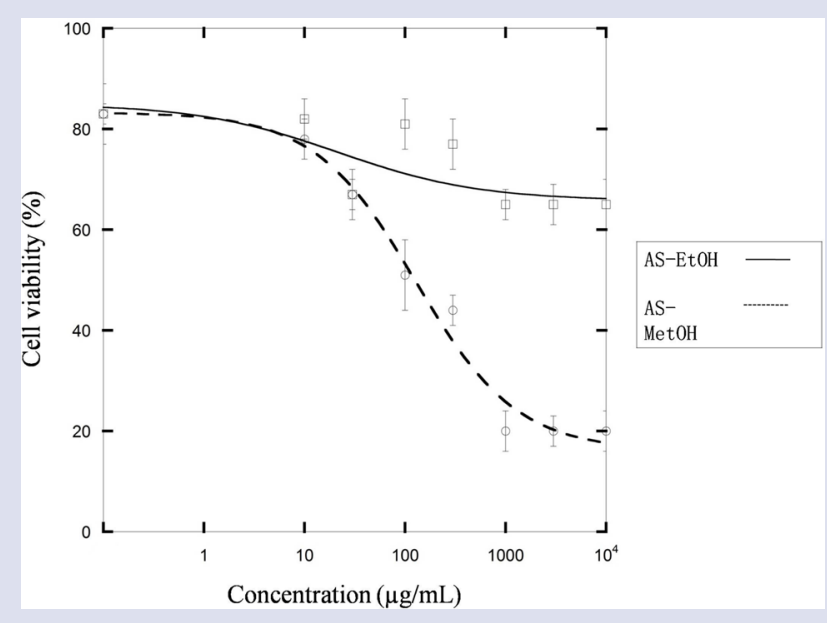

Figure 1: Cytotoxic assay of HeLa Incubated Cells AS-EtOH and ASMetOH for $72 \mathrm{~h}$ Analysed with LDH assay. Graph Fitting for Dose Response Analyses were Conducted with Kaleidagraph Software.

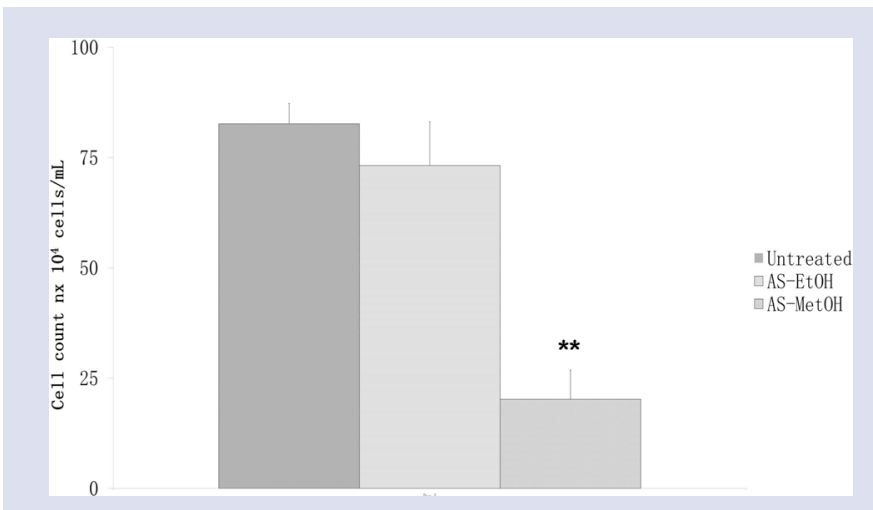

Figure 2: Antiproliferative Assay of HeLa Incubated Cells with AS-EtOH and AS-MetOH Extracts for $72 \mathrm{~h}$. Total Cell Count was Conducted with Trypan Blue Exclusion Assay. ${ }^{*}, t$-test $(p<0.05)$ Significantly Different; ${ }^{* *}(p<0.001)$ Highly Significant Compared to Control.

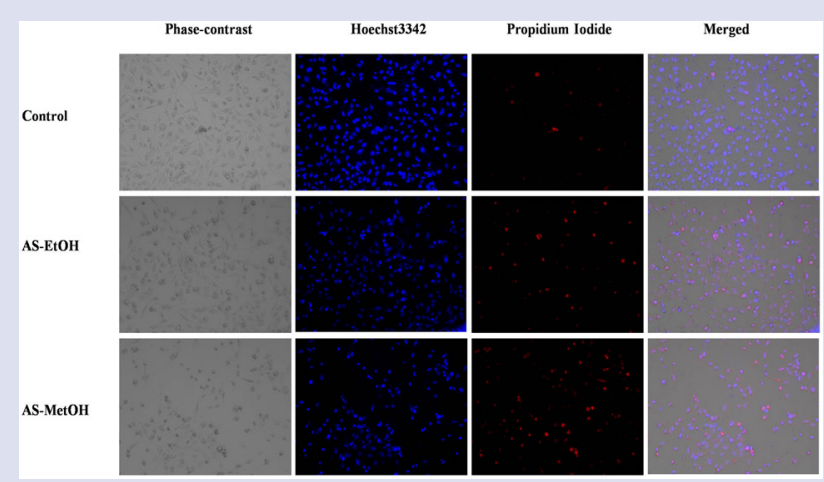

Figure 3: Fluorescence microscopy observation of HeLa cells incubated with $200 \mu \mathrm{g} / \mathrm{mL}$ of AS-EtOH and AS-MetOH extract for $72 \mathrm{~h}$. Blue cells stained with Hoechest3342 indicate live/dead cells. Red cells stained with Propidium lodide indicate dead cells.

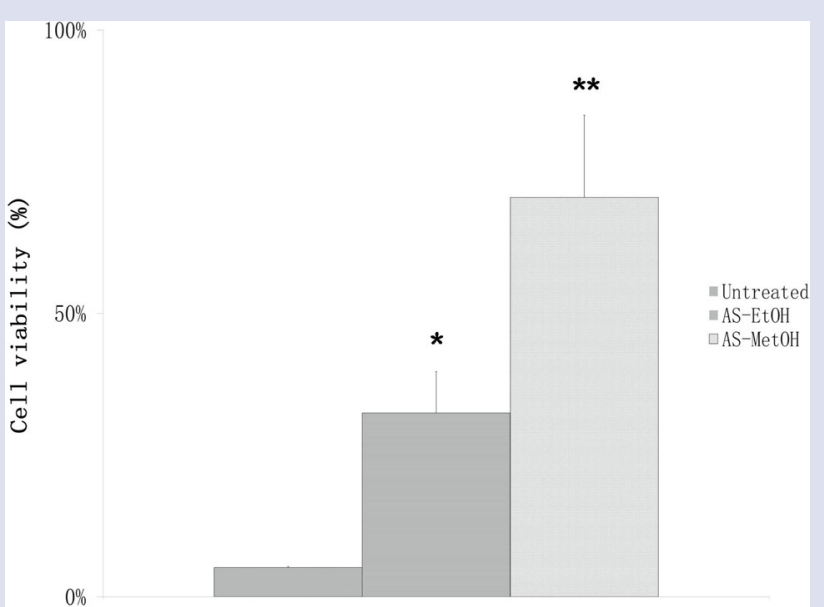

Figure 4: Dead Cell Percentage of HeLa Cells Treated with $200 \mu \mathrm{g} / \mathrm{mL}$ Concentrations of AS-EtOH and AS-MetOH for $72 \mathrm{~h}$. Dead Cell Percentages were Calculated with ImageJ Software. ${ }^{*}, t$-test $(p<0.05)$ Significantly Different; ${ }^{* *}(p<0.001)$ Highly Significant Compared to Control.

to be cells. Untreated cells showed shown low percentage of cells emitting red fluorescence (Dead cells) (Figure 4). Treatment of HeLa cells with AS-EtOH appeared to induce significant percentage of dead cells compared to control. Furthermore, dead cell percentage was highly significant in HeLa cells treated with methanolic extract of Acanthophora spicifera compared to untreated cells. Overall, cells treated with AS-MetOH shown to experience reduction of cell size, cell shrinkage and the formation of blebs on cell surface resulted in the generation of apoptotic bodies.

\section{DNA fragmentation}

DNA fragmentation assay was used to determine the action of AS-EtOH and AS-MetOH extracts which induces cell death in HeLa cell in vitro models. As shown in previous results, AS-MetOH extract was strongly effective in inhibiting HeLa cell proliferation. The ladder pattern was observed for a maximum of 3 days because after that all cells died. DNA fragmentation was clearly observable in AS-MetOH treated HeLa cells (Figure 5). In contrast, cells treated with AS-EtOH did not show indications of apoptotic activity.

\section{DISCUSSION}

Several literatures have evidenced the potential implications of marine products such as macroalgae or seaweeds which exhibit antitumor activity. ${ }^{5,15}$ Despite Indonesia is well known to exhibit high biodiversity of macroalgae, there remains limited information for their potential utilizations. Previous studies have reported potentials of Acanthophora spicifera ethanol extract anticancer potentials. ${ }^{3,9}$ However, the cytotoxic activity presented is ineffective for its development as potential anticancer drug. Hence, in our study we conducted extraction of macroalgae A. spicifera with methanol solvent to evaluate its effects in cytotoxicity A. spicifera against HeLa cells.

The methanol extract of A. spicifera (AS-MetOH) shown significant antiproliferative and cytotoxic activity and potentially induces apoptosis in HeLa cells with $\mathrm{IC}_{50}$ value of $127.3 \pm 33.13 \mu \mathrm{g} / \mathrm{mL}$ (Figure 1 ). In other hand, the ethanol extract of $A$. spicifera (AS-EtOH) cytotoxicity could not be determined with the applied concentrations in this study $(0-200 \mu \mathrm{g} / \mathrm{mL})$. Previous study has demonstrated low cytotoxic activity of A. spicifera crude ethanolic extracts in A549 human non-small lung carcinoma and HeLa cervical cancer cell lines with $\mathrm{IC}_{50}$ of $666 \pm \mu \mathrm{g} / \mathrm{mL}$ and 


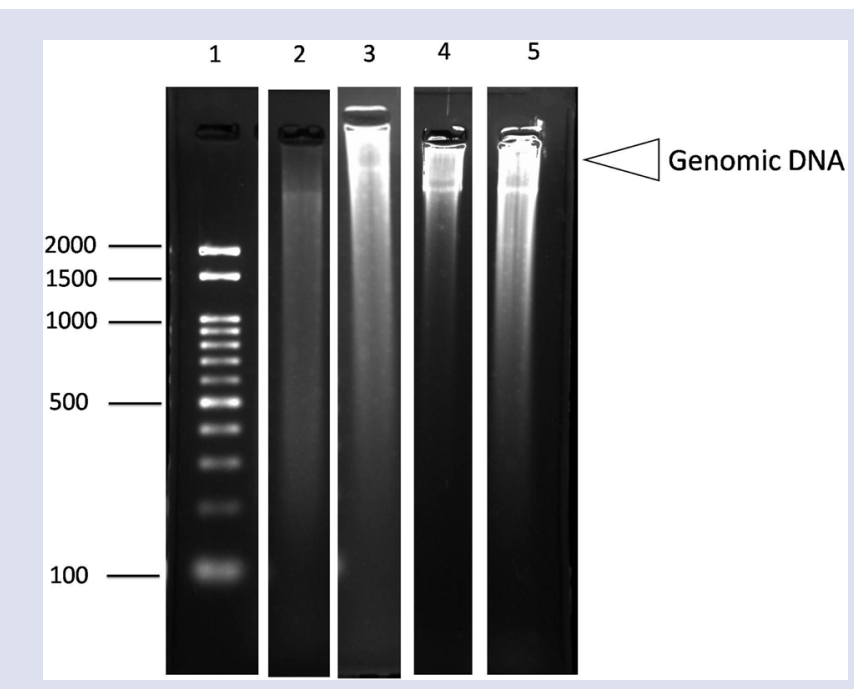

Figure 5: DNA Ladder Assay for Detection of Apoptosis in HeLa Cells Treated with Macroalgae Extracts. HeLa Cells were Cultured in DMEM with $10 \% \mathrm{FBS}$ and $200 \mu \mathrm{g} / \mathrm{mL}$ Concentration of Extracts for $72 \mathrm{~h}$. Apoptotic Cells were Induced by $4 \mu \mathrm{M}$ Staurosporin (STS) as Positive Control. $5 \mu \mathrm{g}$ DNA of each Sample was Electrophorised on a 1.5\% Agarose gel and the gel was stained by ethidium bromide. Lane 1: DNA ladder $1 \mathrm{~kb}$; Lane 2: AS-EtOH; Lane 3: AS-MetOH; Lane 4: Control (no macroalgae extract); Lane 5: STS (Positive control).

$641 \pm 0.21 \mu \mathrm{g} / \mathrm{mL}$ respectively. In general, $\mathrm{IC}_{50}$ values $>500 \mu \mathrm{g} / \mathrm{mL}$ and at least $60 \%$ cell viability are considered as low cytotoxicity effect. ${ }^{16}$ Our results revealed that $\mathrm{AS}-\mathrm{MetOH}$ exhibit higher cytotoxic activity compared to AS-EtOH. Furthermore, antiproliferative assay with trypan blue cell count also revealed that cell proliferation is significantly inhibited by AS-MetOH treatment in HeLa cells for 72h (Figure 2).

Some studies on the effectiveness of extraction methods highlight that methanol extracts exhibit higher anticancer activity. ${ }^{17,18}$ This result could be related to the presence of bioactive metabolites that are soluble in A. spicifera are possibly more effectively extracted in methanol solvent compared to ethanol. Treatment of A. spicifera methanolic extract was found significantly toxic in brine shrimps at 12 and $24 \mathrm{hr} .{ }^{19}$ Furthermore, in vivo studies in cancer induced Swiss Albino mice administered with A. spicifera methanol extract $(200 \mathrm{mg} / \mathrm{kg}$ bw) significantly inhibited the cancer volume, packed cell volume, cancer cell count and haemotological parameters in normal levels. ${ }^{20}$

The macroalgae A. spicifera crude extracts were further evaluated for cancer apoptotic death mode. Apoptosis is the common preliminary targeted mechanism for screening of anticancer potential from novel natural resources. ${ }^{21}$ Moreover, apoptosis is a process which removes individual components of cells and avoids inflammatory effect which is normally associated with necrosis; thus potentially no toxicity to the normal surrounding cells. ${ }^{22}$ To investigate whether the cytotoxic effects of the crude extracts were due to apoptosis, we treated the HeLa cells with AS-EtOH and AS-MetOH for $72 \mathrm{~h}$. After treatments, the cells were then subjected to double viability staining with Hoechst33342 and PI. Membrane permeable Hoechst33342 fluorescence stain stains the nuclei of both live and dead cell. However, Propidium Iodide is not permeable to the cell membrane. ${ }^{23}$ Fluorescence stain PI only stains cells that has lost membrane permeability and binds to DNA by intercalating between the bases. Our results show that AS-EtOH and AS-MetOH induce morphological changes in treated HeLa cells. These changes such as irregular cell size and shape are more observable in AS-MetOH treated cells. Furthermore, cells which emit red fluorescence show higher percentage in AS-MetOH (70\%) treated cells compared to AS-EtOH treated cells (32\%). Propidium Iodide (PI) stain could enter the cell during late-stage apoptosis apart that it also stains dead cells. Hence, cells emitting red fluorescence could possibly be assumed undergoing apoptosis.

Evaluation of apoptosis was further carried out by determining the DNA fragmentation as a result of apoptotic activity by caspase enzymes, indicative of the late stage of apoptosis. ${ }^{24} \mathrm{HeLa}$ cells treated with AS-MetOH showed characteristics of DNA fragmentation similiar to positive control STS (Figure 5). However, DNA fragmentation activity was not observable in AS-EtOH treated cells. DNA fragmentation assay in HeLa cells treated with AS-EtOH and AS-MetOH were observed within maximum of 3 days, because after that all cells died.

\section{CONCLUSION}

In conclusion, AS-MetOH exhibited significant cytotoxic and antiproliferative activity against HeLa cells compared to AS-EtOH. The cytotoxic effect of AS-MetOH appears to have induced apoptosis in HeLA cells. This study is the first to evaluate the potential apoptotic activity induced by macroalgae Acanthophora spicifera. Further investigation on A. spicifera methanol extract cytotoxic activity in a molecular and compound level would be reasonable for development as complementary and alternative anticancer agent.

\section{ACKNOWLEDGEMENT}

We thank Indonesian Ministry of Research, Technology and Higher Education for funding this research through International Collaborative Research Grant scheme (739/UN18.L1/PP/2017).

\section{CONFLICT OF INTEREST}

The authors declare no conflict of interest.

\section{ABBREVIATIONS}

AS-EtOH: Acanthophora spicifera Ethanol Extract; AS-MetOH: Acanthophora spificera methanol Extract; DMEM: Dulbecco's Modified Eagle Medium; DNA: Deoxyribonucleic Acid; EC $_{50}$ : 50\% Effective Concentration; LDH: Lactate Dehydrogenase; NAD: Nicotinamide Adenine Dinucleotide; PI: Propidium Iodide; PMS: Phenazine Methyl Sulfate; STS: Staurosporin; WST-1: Water Soluble Tetrazolium-1.

\section{REFERENCES}

1. Bray F, Ferlay J, Soerjomataram I, Siegel RL, Torre LA, Jemal A. Global cancer statistics 2018: GLOBOCAN estimates of incidence and mortality worldwide for 36 cancersss in 185 countries. CA Cancer J Clin. 2018;68(6):394-424. doi:10.3322/caac.21492

2. Zhang QY, Wang FX, Jia KK, Kong LD. Natural Product Interventions for Chemotherapy and Radiotherapy-Induced Side Effects. Front Pharmacol. 2018;9:1253. doi:10.3389/fphar.2018.01253

3. Sithranga BN, Kathiresan K. Anticancer Drugs from Marine Flora: An Overview J Oncol. 2010;2010. doi:10.1155/2010/214186

4. Rocha DHA, Seca AML, Pinto DCGA. Seaweed Secondary Metabolites in vitro and in vivo Anticancer Activity. Mar Drugs. 2018;16(11):410. doi:10.3390/ md16110410

5. Lefranc F, Koutsaviti A, loannou E, et al. Algae metabolites: from in vitro growth inhibitory effects to promising anticancer activity. Nat Prod Rep. 2018 doi:10.1039/c8np00057c

6. Yende SR, Harle UN, Chaugule BB. Therapeutic potential and health benefits of Sagassum species. Pharmacogn Rev. 2014;8(15):1-7. doi:10.4103/09737847.125514

7. Moussavou G, Kwak DH, Obiang-Obonou BW, et al. Anticancer Effects of Different Seaweeds on Human Colon and Breast Cancers. Mar Drugs. 2014;12(9):4898-911. doi:10.3390/md12094898

8. Suresh KK, Ganesan K, Subba RPV. Seasonal variation in nutritional composition of Kappaphycus alvarezii (Doty) Doty—an edible seaweed. J Food Sci Technol. 2015;52(5):2751-60. doi:10.1007/s13197-014-1372-0

9. Tumoricidal effect of the red algae Acanthophora spicifera on Ehrlich's ascites carcinoma cells. Request PDF. https://www.researchgate.net/publication/ 
222088732_Tumoricidal_effect_of_the_red_algae_Acanthophora_spicifera_on_ Ehrlich's_ascites_carcinoma_cells

10. Algaebase: Listing the World's Algae. http://www.algaebase.org/.

11. Brown Seaweed Egregia menziesii's Cytotoxic Activity against Brain Cancer Cell Lines. - PubMed - NCBI. https://www.ncbi.nlm.nih.gov/pubmed/30641974.

12. In vitro cytotoxicity assays: comparison of $\mathrm{LDH}$, neutral red, MTT and protein assay in hepatoma cell lines following exposure to cadmium chloride. PubMed - NCBI. https://www.ncbi.nlm.nih.gov/pubmed/16111842

13. Assessment of Cell Viability with Single-, Dual-and Multi-Staining Methods Using Image Cytometry. - PubMed - NCBI. https://www.ncbi.nlm.nih.gov/ pubmed/28470515.

14. DNA fragmentation, an indicator of apoptosis, in cultured black tiger shrimp Penaeus monodon infected with White Spot Syndrome Virus (WSSV). PubMed - NCBI. https://www.ncbi.nlm.nih.gov/pubmed/11324818.

15. Anticancer activity of seaweeds. PubMed - NCBI. https://www.ncbi.nlm.nih gov/pubmed/29107095

16. Mechanisms Underlying Cytotoxicity Induced by Engineered Nanomaterials: A Review of in vitro Studies. https://www.ncbi.nlm.nih.gov/pmc/articles/ PMC5304664/.

17. Martins RM, Nedel F, Guimarães VBS, et al. Macroalgae Extracts from Antarctica have Antimicrobial and Anticancer Potential. Front Microbiol. 2018:9:412. doi:10.3389/fmicb.2018.00412

18. Iloki-Assanga SB, Lewis-Luján LM, Lara-Espinoza CL, et al. Solvent effects on phytochemical constituent profiles and antioxidant activities, using four different extraction formulations for analysis of Bucida buceras L. and Phoradendron californicum. BMC Res Notes. 2015;8(1):396. doi:10.1186/s13104-015-1388-1

19. Zakaria NA, Ibrahim D, Sulaiman SF, Supardy NA. Assessment of antioxidant activity, total phenolic content and in- vitro toxicity of Malaysian red seaweed, Acanthophora spicifera. J Chem Pharm Res. 2011;10.

20. In-vivo anticancer activity of red algae (Gelidiela acerosa and Acanthophora spicifera) durai durai - Academia.edu. https://www.academia.edu/11333459//NVVOAnticancer_ACTIVITY_OF_RED_ALGAE_GELIDIELA_ACEROSA_AND_ACANTHOPHORA_SPICIFERA.

21. Antitumor Potential of Marine Natural Products: A Mechanistic Investigation PubMed - NCBI. https://www.ncbi.nlm.nih.gov/pubmed/28925876

22. Saikumar $P$, Dong Z, Mikhailov V, Denton M, Weinberg JM, Venkatachalam MA Apoptosis: definition, mechanisms and relevance to disease. Am J Med. 1999;107(5):489-506.

23. Foglieni C, Meoni C, Davalli AM. Fluorescent dyes for cell viability: an application on prefixed conditions. Histochem Cell Biol. 2001;115(3):223-9.

24. Chia YY, Kanthimathi MS, Khoo KS, Rajarajeswaran J, Cheng HM, Yap WS Antioxidant and cytotoxic activities of three species of tropical seaweeds. BMC Complement Altern Med. 2015;15(1):339. doi:10.1186/s12906-015-0867-1

\section{GRAPHICAL ABSTRACT}

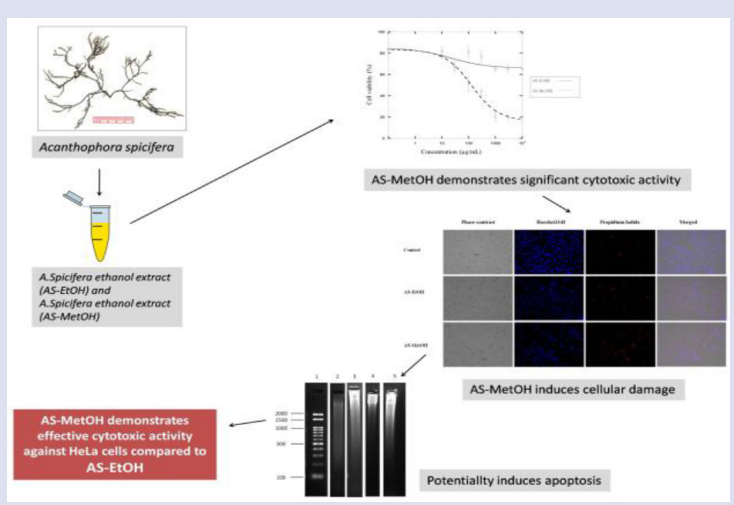

\section{SUMMARY}

- Red Macroalgae Acanthophora spicifera (AS) has high abundance in Indonesian coastal waters. Several studies have evidenced potential anticancer activity of AS. However, previous study conducted with ethanol extract of AS resulted in low cytotoxic activity. In this study, we evaluated AS anticancer potential in a different solvent which is methanol. Current results show that AS Methanol Extract (AS-MetOH) demonstrates higher cytotoxicity compared to AS Ethanol Extract (AS-EtOH) in HeLa cells. Furthermore, treatment with AS-MetOH in HeLa cells was seen to induce apoptosis. In the other hand, AS-EtOH treatment apoptotic activity was not clear in our treatments. Further purification to obtain a potentially active and pure compound from Acanthophora spicifera crude methanol extract would be undertaken in the future for its potential development as natural anticancer agent.

\section{ABOUT AUTHORS}

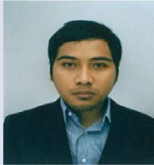

Eka Sunarwidhi Prasedya, MSc.,PhD: Is currently working as a staff lecturer in Biology, Department Mataram University, Indonesia. He also is a research staff in Fukushima Medical University (FMU), Japan. He finished his $\mathrm{PhD}$ in the field of Biomedicine in FMU Department of Cellular and Integrative Physiology. He did his master in Malaya University Institute of Ocean and Earth Sciences studying marine biotechnology of macroalgae. Now, he is conducting research in investigation of various pharmaceutical applications of macroalgae.

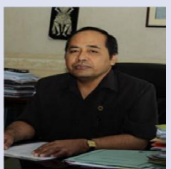

Prof H Sunarpi, PhD: Was the rector of Mataram University, Indonesia for 8 years. Currently he is the head of Bioscience and Biotechnology Research Centre, Mataram University. He Finished his PhD at La Trobe University, Melbourne, Australia. His research areas include Plant Physiology and Molecular mechanisms. Now, he is doing a lot of investigations in potential of Indonesian seaweeds for various applications.

Cite this article: Prasedya ES, Martyasari NWR, Hamdin CD, Miyake M, Kobayashi D, Widyastuti S, Hazama A, Sunarpi H. Effectiveness of Methanol Solvent Extraction for Red Macroalgae Acanthophora spicifera Antitumoric Activity. Pharmacog J. 2019;11(3):450-4. 